\title{
Rationalizing personal protective equipment (PPE) in radiology in the time of COVID-19
}

\author{
Binit Sureka, Pawan Kumar Garg, Pushpinder Singh Khera, Arvind Sinha1', Sanjeev Misra² \\ Departments of Diagnostic and Interventional Radiology, ${ }^{1}$ Professor Pediatric Surgery and Medical Superintendent, ${ }^{2}$ Professor \\ Surgical Oncology, Director and CEO, All India Institute of Medical Sciences, Basni, Jodhpur, Rajasthan, India
}

Correspondence: Dr. Binit Sureka, Associate Professor, Department of Diagnostic and Interventional Radiology, Deputy Medical Superintendent, All India Institute of Medical Sciences, Basni, Jodhpur - 342 005, Rajasthan, India. E-mail: binitsurekapgi@gmail.com

\section{Introduction}

The COVID-19 pandemic, also known as the coronavirus pandemic, is caused by severe acute respiratory syndrome coronavirus 2 (SARSCoV2). The outbreak was first identified in Wuhan, China, in December 2019. The World Health Organization declared the outbreak a public health emergency of international concern on January 30, 2020 and a pandemic on March 11, 2020. As of May 31, 2020, the Ministry of Health and Family Welfare have confirmed a total of 89995 cases, 86983 recoveries (including 1 migration), and 5164 deaths in the country. ${ }^{[1]}$

The virus primarily spreads among people during close contact, most often via small droplets produced by coughing, sneezing, and talking.

\section{Personal Protective Equipment (PPE)}

Personal Protective Equipments (PPEs) are protective gears designed to safeguard the health of workers by minimizing the exposure to a biological agent. Occupational Safety and Health Administration (OSHA) defines PPE as "specialized clothing or equipment worn by an employee for protection against an infectious material". ${ }^{[2]}$

\section{Components of PPE}

Coverall, gloves, shoe cover, triple-layer mask, N95 respirator, head cover (hood), face shield, and goggles.

\section{Levels of PPE}

Level 1 PPE: For Standard Infection control precautions - It includes disposable gown and disposable gloves. If risk of spraying or splashing is anticipated, surgical mask and face shield/goggles are recommended.

Level 2 PPE: For direct/indirect contact precautions/ droplet precautions/airborne precautions - It includes fluid-resistant disposable gown and disposable gloves. If risk of spraying or splashing is anticipated, surgical mask and face shield/goggles are recommended. Head cover and N95 respirator are to be considered in cases of airborne infection.

Level 3 PPE: Enhanced precautions for suspected or confirmed infectious diseases of high consequence which spread by direct/indirect contact or by airborne route - It includes fluid-resistant coverall with hood/long-sleeved gown with disposable fluid-resistant hood, N95 mask, face shield, two sets of gloves, and shoe covers.

\section{Details of Each Element of PPE}

Fluid-resistant coverall: The coverall should have following specifications - Impermeable to blood and body fluids, single use, meets or exceeds ISO 16603 class 3 exposure pressure, or equivalent. The coverall should be SITRA or DRDO approved if manufactured in India.

Disposable gown: Impermeable to blood and body fluids, single use.

Disposable gloves: Nitrile nonsterile, powder-free gloves are preferred.

Value of gloves in COVID-19 scenario: Gloves should be worn when providing direct care for a COVID-19 case and then removed, followed by hand hygiene. Extended use of gloves for caring COVID-19 cases is not recommended. Changing gloves between dirty and clean tasks during care to a patient and when moving from a patient to another, accompanied by hand hygiene, is absolutely necessary. Double gloving is not recommended, except for surgical procedures that carry a high risk of rupture.

Triple-layer surgical mask: The triple-layer surgical mask should be made of a melt-blown polymer, most commonly polypropylene, placed between nonwoven fabrics. 
Table 1: Appropriate use of PPE in non COVID areas in diagnostic radiology ${ }^{[3-7]}$

\begin{tabular}{|c|c|c|c|c|c|}
\hline \multicolumn{6}{|c|}{ Diagnostic radiology non-covid areas } \\
\hline Setting & $\begin{array}{l}\text { Target } \\
\text { personnel }\end{array}$ & PPE & $\begin{array}{l}\text { Level } \\
\text { of PPE }\end{array}$ & Remarks & Patient oriented \\
\hline $\begin{array}{l}\text { Radiology } \\
\text { Reception Area/ } \\
\text { Help Desk }\end{array}$ & $\begin{array}{l}\text { Receptionist/Data } \\
\text { entry operator }\end{array}$ & Triple-layer mask & - & $\begin{array}{l}\text { Ideally, build glass/plastic screens to create a barrier } \\
\text { between health care workers and patients }\end{array}$ & $\begin{array}{l}\text { Physical distancing to be followed } \\
\text { at all times } \\
\text { Patients should wear a cloth } \\
\text { mask/triple-layer mask at all times }\end{array}$ \\
\hline X-ray & $\begin{array}{l}\text { Radiologist/ } \\
\text { Technician }\end{array}$ & $\begin{array}{l}\text { Gown and } \\
\text { triple-layer mask }\end{array}$ & - & - & $\begin{array}{l}\text { Patients should wear a cloth } \\
\text { mask/triple-layer mask at all times }\end{array}$ \\
\hline $\begin{array}{l}\text { Fluoroscopy } \\
\text { procedures }\end{array}$ & $\begin{array}{l}\text { Radiologist/ } \\
\text { Nurse/Technician }\end{array}$ & $\begin{array}{l}\text { Gown, triple-layer } \\
\text { mask, gloves }\end{array}$ & Level 1 & $\begin{array}{l}\text { Face shield/goggles with a visor, when splash of body } \\
\text { fluid is expected }\end{array}$ & $\begin{array}{l}\text { Patients should wear a cloth } \\
\text { mask/triple-layer mask at all times }\end{array}$ \\
\hline Ultrasound & $\begin{array}{l}\text { Radiologist/ } \\
\text { Nurse/Attendant }\end{array}$ & $\begin{array}{l}\text { Gown, triple-layer } \\
\text { mask }\end{array}$ & - & $\begin{array}{l}\text { Ideally, build glass/plastic screens with a hole for hand to } \\
\text { create a barrier }\end{array}$ & $\begin{array}{l}\text { Patients should wear a cloth } \\
\text { mask/triple-layer mask at all times }\end{array}$ \\
\hline Mammography ${ }^{[7]}$ & $\begin{array}{l}\text { Radiologist/ } \\
\text { Technician }\end{array}$ & $\begin{array}{l}\text { Gown, triple-layer } \\
\text { mask, gloves }\end{array}$ & Level 1 & - & $\begin{array}{l}\text { Patients should wear a cloth } \\
\text { mask/triple-layer mask at all times }\end{array}$ \\
\hline СT & $\begin{array}{l}\text { Radiologist/ } \\
\text { Nurse/Technician }\end{array}$ & $\begin{array}{l}\text { Gown, triple-layer } \\
\text { mask }\end{array}$ & - & $\begin{array}{l}\text { Face shield/goggles with a visor, when splash of } \\
\text { body fluid is expected or a patient being imaged is on } \\
\text { ventilator }\end{array}$ & $\begin{array}{l}\text { Patients should wear a cloth } \\
\text { mask/triple-layer mask at all times }\end{array}$ \\
\hline MRI & $\begin{array}{l}\text { Radiologist/ } \\
\text { Nurse/Technician }\end{array}$ & $\begin{array}{l}\text { Gown, triple-layer } \\
\text { mask }\end{array}$ & - & $\begin{array}{l}\text { Face shield/goggles with a visor, when splash of } \\
\text { body fluid is expected or a patient being imaged is on } \\
\text { ventilator }\end{array}$ & $\begin{array}{l}\text { Patients should wear a cloth } \\
\text { mask/triple-layer mask at all times }\end{array}$ \\
\hline
\end{tabular}

Hospital Attendant and Housekeeping staff in non-COVID areas should wear triple-layer mask, gown, heavy duty gloves, heavy duty boots, goggles or face shield if splash of fluid is expected. Anywhere where there is aerosol generating procedure, Level 3 PPE to be used. PPEs are not alternative to basic preventive public health measures such as hand hygiene, respiratory etiquettes which must be followed at all times. Doctor and nursing staff should wear gloves while handling patients whose clothes are visibly soiled

Table 2: Appropriate use of PPE in non COVID areas in Interventional Radiology and all COVID areas in radiology ${ }^{[3-7]}$

\begin{tabular}{|c|c|c|c|c|c|}
\hline \multicolumn{6}{|c|}{ Interventional radiology non-covid areas } \\
\hline Setting & Target personnel & PPE & $\begin{array}{l}\text { Level } \\
\text { of PPE }\end{array}$ & Remarks & Patient oriented \\
\hline $\begin{array}{l}\text { Emergency Vascular/ } \\
\text { Nonvascular } \\
\text { Intervention procedure }\end{array}$ & $\begin{array}{l}\text { Radiologist/Nurse/ } \\
\text { Technician }\end{array}$ & $\begin{array}{l}\text { Water impervious gown, } \\
\text { gloves, shoe cover, head cover } \\
\text { or cap, triple-layer mask, and } \\
\text { goggles/face shield if aerosol } \\
\text { generation/splash expected }\end{array}$ & Level 3 & $\begin{array}{l}\text { - Ideally, build glass/plastic screens to create a } \\
\text { barrier between health care workers and patients } \\
\text { - N95 respirator to be used if patient from hot } \\
\text { spot/containment zone }\end{array}$ & $\begin{array}{l}\text { Patients should wear a } \\
\text { cloth mask/triple-layer } \\
\text { mask at all times if } \\
\text { feasible }\end{array}$ \\
\hline $\begin{array}{l}\text { Elective Vascular/ } \\
\text { Nonvascular } \\
\text { Intervention procedure }\end{array}$ & $\begin{array}{l}\text { Radiologist/Nurse/ } \\
\text { Technician }\end{array}$ & $\begin{array}{l}\text { Linen gown, gloves, shoe cover, } \\
\text { head cover or cap, triple-layer } \\
\text { mask, and face shield if feasible }\end{array}$ & Level 2 & $\begin{array}{l}\text { - N95 respirator to be used if patient from hot } \\
\text { spot/containment zone } \\
\text { - Any procedure involving lung or pleural cavity } \\
\text { wear full PPE }\end{array}$ & $\begin{array}{l}\text { Patients should wear a } \\
\text { cloth mask/triple-layer } \\
\text { mask at all times }\end{array}$ \\
\hline $\begin{array}{l}\text { Emergency USG/CT } \\
\text { guided procedures }\end{array}$ & $\begin{array}{l}\text { Radiologist/Nurse/ } \\
\text { Technician }\end{array}$ & $\begin{array}{l}\text { Water impervious gown, } \\
\text { gloves, shoe cover, head cover } \\
\text { or cap, triple-layer mask, and } \\
\text { goggles/face shield if aerosol } \\
\text { generation/splash expected }\end{array}$ & Level 2 & $\begin{array}{l}\text { Ideally, build glass/plastic screens to create a } \\
\text { barrier between health care workers and patients } \\
\text { - N95 respirator to be used if patient from hot } \\
\text { spot/containment zone }\end{array}$ & $\begin{array}{l}\text { Patients should wear a } \\
\text { cloth mask/triple-layer } \\
\text { mask at all times if } \\
\text { feasible }\end{array}$ \\
\hline $\begin{array}{l}\text { Elective USG/CT/ } \\
\text { Mammography } \\
\text { guided procedures }\end{array}$ & $\begin{array}{l}\text { Radiologist/Nurse/ } \\
\text { Technician }\end{array}$ & $\begin{array}{l}\text { Linen gown, gloves, shoe cover, } \\
\text { head cover or cap, triple-layer } \\
\text { mask, and face shield if feasible }\end{array}$ & Level 2 & $\begin{array}{l}\text { - N95 respirator to be used if patient from hot } \\
\text { spot/containment zone } \\
\text { - Any procedure involving lung or pleural cavity } \\
\text { wear full PPE }\end{array}$ & $\begin{array}{l}\text { Patients should wear a } \\
\text { cloth mask/triple-layer } \\
\text { mask at all times if } \\
\text { feasible }\end{array}$ \\
\hline \multicolumn{6}{|c|}{ All radiology procedures in covid areas } \\
\hline $\begin{array}{l}\text { All Diagnostic } \\
\text { and Interventional } \\
\text { procedures }\end{array}$ & $\begin{array}{l}\text { Radiologist/ } \\
\text { Nurse/Technician/ } \\
\text { Housekeeping/ } \\
\text { Hospital Attendant }\end{array}$ & Full component of PPE & Level 3 & $\begin{array}{l}\text { - Physical distancing to be followed at all times } \\
\text { - Ideally, build glass/plastic screens to create a } \\
\text { barrier between health care workers and patients }\end{array}$ & $\begin{array}{l}\text { Patients should wear a } \\
\text { cloth mask/triple-layer } \\
\text { mask at all times if } \\
\text { feasible }\end{array}$ \\
\hline
\end{tabular}

Hospital Attendant and Housekeeping staff in non-COVID areas should wear triple-layer mask, gown, heavy duty gloves, heavy duty boots, angoggles or face shield if splash of fluid is expected. Anywhere where there is aerosol generating procedure, Level 3 PPE to be used. PPEs are not alternative to basic preventive public health measures such as hand hygiene and respiratory etiquettes which must be followed at all times

N95 mask: Ideally should be NIOSH N95, EN 149 FFP2, or equivalent.

Triple-layer mask or N95: N95 masks should be used in COVID suspect and positive cases. Surgical mask should only be used for routine cases in which there is no suspicion for COVID infection. Only in crisis times and nonavailability of N95 masks, surgical mask with visor may be considered for examining COVID suspect cases with all due precautions. 
Face shield: It should be made of clear plastic and provide good visibility to both the wearer and the patient. It should be fog resistant, should have adjustable band to attach firmly around the head and fit snuggly against the forehead, and completely cover the sides and length of the face.

Goggles: Goggles should have transparent glasses with zero power. It should be covered from all sides with elastic band/or adjustable holder. It should have good seal with the skin of the face and should be fog and scratch resistant.

Shoe cover: It should be made up of the same fabric as of the coverall and should cover the entire shoe and reach above the ankles.

\section{Rational Use of PPE in Radiology}

Various PPEs that have to be used in diagnostic as well as interventional radiology services are listed in Tables 1 and 2. ${ }^{[3-6]}$

\section{Conclusion}

As the Government is in the process of opening the lockdown and stressing on opening of non-COVID hospitals, diagnostic centers will soon be flooded with patients for imaging. Rational and appropriate use of PPE that is reusable, economical, and recyclable is the need of hour. The above guidelines depend upon the resources available with the institutions, hospitals, and diagnostic centers. One can think of using their own customized PPEs as many local textile manufacturers are coming up with economical solutions as announced by our Honourable Prime Minister for implementing the Atmanirbhar Bharat Abhiyan scheme.

\section{References}

1. Ministry of Health and Family Welfare [Internet]. Available from: https://www.mohfw.gov.in/. [Last cited on 2020 May 25].

2. Centres for Disease Control and Prevention [Internet]. Available from: https://www.cdc.gov/HAI/pdfs/ppe/PPEslides6-29-04 pdf. [Last cited on 2020 Apr 05].

3. World Health Organization. [Internet]. Available from: https://www. who.int/publications-detail/rational -use-of-personal-protective -equipment-for-coronavirus-disease-(covid-19)-and-considerations -during-severe-shortages. [Last cited on 2020 Apr 06].

4. Ministry of Health and Family Welfare [Internet] .Available from: https://www.mohfw.gov.in/pdf/ GuidelinesonrationaluseofPersonalProtectiveEquipment.pdf. [Last cited on 2020 Apr 05].

5. Ministry of Health and Family Welfare [Internet]. Available from: https://www.mohfw.gov.in/pdf/Additionalguidelines onrationaluse of PersonalProtective Equipment settingapproachforHealthfunctionariesworkinginnonCOVIDareas. pdf. [Last cited on 2020 Apr 05].

6. National Centre for Disease Control [Internet]. Available from: https://www.cdc.gov/coronavirus/2019-ncov/hcp/ppe-strategy/ isolation-gowns.html. [Last cited on 2020 Apr 05].

7. Moy L, Toth HK, Newell MS, Plecha D, Leung JWT, Harvey JA. Response to COVID-19 in breast imaging. J Breast Imaging 2020;2:180-5.

This is an open access journal, and articles are distributed under the terms of the Creative Commons Attribution-NonCommercial-ShareAlike 4.0 License, which allows others to remix, tweak, and build upon the work non-commercially, as long as appropriate credit is given and the new creations are licensed under the identical terms.

\begin{tabular}{|l|l|}
\hline \multicolumn{2}{|c|}{ Access this article online } \\
\hline Quick Response Code: & \\
\hline & Website: \\
\hline & www.ijri.org \\
\cline { 2 - 3 } & DOI: \\
\hline
\end{tabular}

Cite this article as: Sureka B, Garg PK, Khera PS, Sinha A, Misra S. Rationalizing personal protective equipment (PPE) in radiology in the time of COVID-19. Indian J Radiol Imaging 2021;31:S204-6.

Received: 13-May-2020

Revised: 29-May-2020

Accepted: $17-\mathrm{Jul}-2020$ 